\title{
Structure and Migration in U.S. Blumeria graminis f. sp. tritici Populations
}

\author{
Christina Cowger, Ryan Parks, and Evsey Kosman
}

First and second author: U.S. Department of Agriculture-Agricultural Research Service, CB7616, Department of Plant Pathology, North Carolina State University, Raleigh 27695; and third author: Faculty of Life Sciences, Institute for Cereal Crops Improvement, Tel Aviv University, Tel Aviv 69978, Israel.

Accepted for publication 19 November 2015.

\begin{abstract}
Cowger, C., Parks, R., and Kosman, E. 2016. Structure and migration in U.S. Blumeria graminis f. sp. tritici populations. Phytopathology 106:295-304.

While wheat powdery mildew occurs throughout the south-central and eastern United States, epidemics are especially damaging in the Mid-Atlantic states. The structure of the U.S. Blumeria graminis f. sp. tritici population was assessed based on a sample of 238 single-spored isolates. The isolates were collected from 16 locations in 12 states (18 site-years) as chasmothecial samples in 2003 or 2005 , or as conidial samples in 2007 or 2010. DNA was evaluated using nine single nucleotide polymorphism (SNP) markers in four housekeeping genes, and 10 simple sequence repeat (SSR) markers. The SSR markers were variably polymorphic, with allele numbers ranging from 3 to 39 per locus. Genotypic diversity was high (210 haplotypes) and in eight of the site-years, every isolate had a different SSR genotype. SNP haplotypic diversity was lower; although 15 haplotypes were identified, the majority of isolates possessed one of two haplotypes. The chasmothecial samples showed no evidence of linkage disequilibrium $(P=0.36)$,

while the conidial samples did $(P=0.001)$, but the two groups had nearly identical mean levels of genetic diversity, which was moderate. There was a weakly positive relationship between genetic distance and geographic distance $\left(R^{2}=0.25, P=0.001\right)$, indicating modest isolation by distance. Most locations in the Mid-Atlantic and Great Lakes regions clustered together genetically, while Southeast locations formed a distinct but adjacent cluster; all of these were genetically separated from Southern Plains locations and an intermediate location in Kentucky. One-way migration was detected at a rate of approximately five individuals per generation from populations west of the Appalachian Mountains to those to the east, despite the fact that the Atlantic states experience more frequent and damaging wheat mildew epidemics. Overall, the evidence argues for a large-scale mosaic of overlapping populations that re-establish themselves from local sources, rather than continentalscale extinction and re-establishment, and a low rate of long-distance dispersal roughly from west to east, consistent with prevailing wind directions.
\end{abstract}

Blumeria graminis (DC.) E. O. Speer f. sp. tritici (Em. Marchal) causes powdery mildew of wheat (Triticum aestivum L.) and is a major pathogen in the eastern winter wheat region of the United States and in temperate, moist wheat-growing areas worldwide. The U.S. Mid-Atlantic states (Delaware, Maryland, Virginia, North Carolina, and South Carolina) are frequently subject to damaging wheat powdery mildew epidemics, while economically important epidemics occur less frequently in the Southeast, Northeast, and Great Plains states, and recently in the Pacific Northwest. On susceptible varieties, yield losses up to $34 \%$ have been reported (Niewoehner and Leath 1998).

B. graminis f. sp. tritici is an obligate, biotrophic ascomycete that reproduces both sexually and asexually. On winter cereals, sexual reproduction occurs in late spring prior to host senescence (Götz et al. 1996), when compatible mating types combine to form chasmothecia. Within chasmothecia, the fungus may remain dormant and survive the summer in the absence of a living host. Ascospores may be released from chasmothecia to serve as primary inoculum for epidemic initiation in fall-sown cereals (Götz et al. 1996; Koltin and Kenneth 1970), although chasmothecia often fail to mature and/or release ascospores (authors' personal observation; Turner 1956), possibly due to poor nutrient availability for fungal development (Götz and Boyle 1998), shortness of the epidemic, or weather conditions (Turner 1956). After initial infections in late fall or winter, mycelial growth and sporulation is slow but continuous during the

Corresponding author: C. Cowger; E-mail address: Christina.Cowger@ ars.usda.gov

http://dx.doi.org/10.1094/PHYTO-03-15-0066-R

This article is in the public domain and not copyrightable. It may be freely reprinted with customary crediting of the source. The American Phytopathological Society, 2016. winter except during frosts (Cherewick 1944; Turner 1956), and the infections become more active during milder, humid weather. Under peak conditions in early spring, multiple cycles of asexual reproduction yield copious quantities of locally adapted, clonal conidia (Wolfe and Schwarzbach 1978).

Recent years have seen significant discoveries in Blumeria genomics. B. graminis f. sp. tritici was recently revealed to have an unusually large genome for a plant-parasitic fungus $(\sim 174 \mathrm{Mb})$, composed over $90 \%$ of transposable DNA element (TE) sequences (Parlange et al. 2011; Wicker et al. 2013). Similarly, the closely related barley powdery mildew forma specialis (B. graminis f. sp. hordei) has a very large genome $(\sim 120 \mathrm{Mb})$ consisting to an estimated $64 \%$ of TEs (Spanu et al. 2010). Massive genome expansion in the mildews to sizes over four times the median of other ascomycetous genomes is proposed to be a consequence of obligate biotrophy (Spanu et al. 2010). The high rate of similarity among repeat copies in $B$. graminis f. sp. tritici (Parlange et al. 2011) and comparisons with B. graminis f. sp. hordei sequences (Oberhaensli et al. 2011) suggest that $B$. graminis f. sp. tritici TE proliferation and genome expansion occurred after the two formae speciales diverged (Parlange et al. 2011), although the date of that divergence is controversial (Troch et al. 2014).

Historically, surveys of wheat powdery mildew in the United States and Europe have focused on distribution of virulence frequencies (Jevtic et al. 1991; Leath and Murphy 1985; Limpert et al. 1987; Limpert et al. 1999; Namuco et al. 1987; Niewoehner and Leath 1998; Parks et al. 2008; Persaud and Lipps 1995; Svec and Miklovicova 1998). These results are useful for wheat growers and resistance breeding but have limited utility for inferences about population structure, as regional differences in virulence frequencies likely reflect the selective effects of locally grown cultivars and provide little insight into population-structuring forces such as genetic drift or gene flow (Parks et al. 2009). Recently, molecular 
markers amplifying specific $B$. graminis f. sp. tritici regions with single nucleotide polymorphisms (SNPs) and simple sequence repeats (SSRs) have been developed to assess population structure of powdery mildew (Parks et al. 2009, 2011). Selectively neutral SSRs and SNPs allow for model-based analysis of population history and structuring forces (Beerli and Palczewski 2010).

Researchers in Europe and the UK have inferred that populations of $B$. graminis are strongly influenced by long-distance dispersal (LDD). Although they are ephemeral (Cherewick 1944), both conidia and ascospores of $B$. graminis f. sp. tritici are wind-dispersed and reportedly have potential for $\mathrm{LDD}$, e.g., the $\sim 650 \mathrm{~km}$ from the UK to Denmark (Hermansen et al. 1978; Wolfe and Schwarzbach 1978). Similarities in the early-1980s evolution of B. graminis f. sp. hordei virulence profiles in widely separated European countries led observers to implicate migration, although it was uncertain whether the transport occurred in a single event or by multiple steps (Limpert et al. 1999; Wolfe et al. 1992). A "European mildew path" was proposed, with prevailing west-to-east winds accounting for virulence complexity gradients (Limpert et al. 1999). On the basis of small B. graminis f. sp. tritici samples and larger B. graminis f. sp. hordei samples, evaluated with amplified fragment length polymorphisms (AFLPs), Wyand and Brown (2003) concluded that LDD accounted for the lesser differentiation between populations on different continents than between those in more proximal locations within Europe.

In the New World, analysis of eastern U.S. B. graminis f. sp. tritici isolates with SNP markers provided evidence for recent introduction of the pathogen into the United States, perhaps concurrent with the introduction of wheat by European colonists (Parks et al. 2009). In addition, population subdivision between the southeastern and MidAtlantic states was found. A high level of homoplasy between unlinked SNP loci was attributed to the significant role played by sexual recombination (Parks et al. 2009).

In the United States, wheat powdery mildew is primarily managed through fungicide applications and resistance $(\mathrm{Pm})$ genes deployed in partially resistant genetic backgrounds (Cowger et al. 2012; Leath

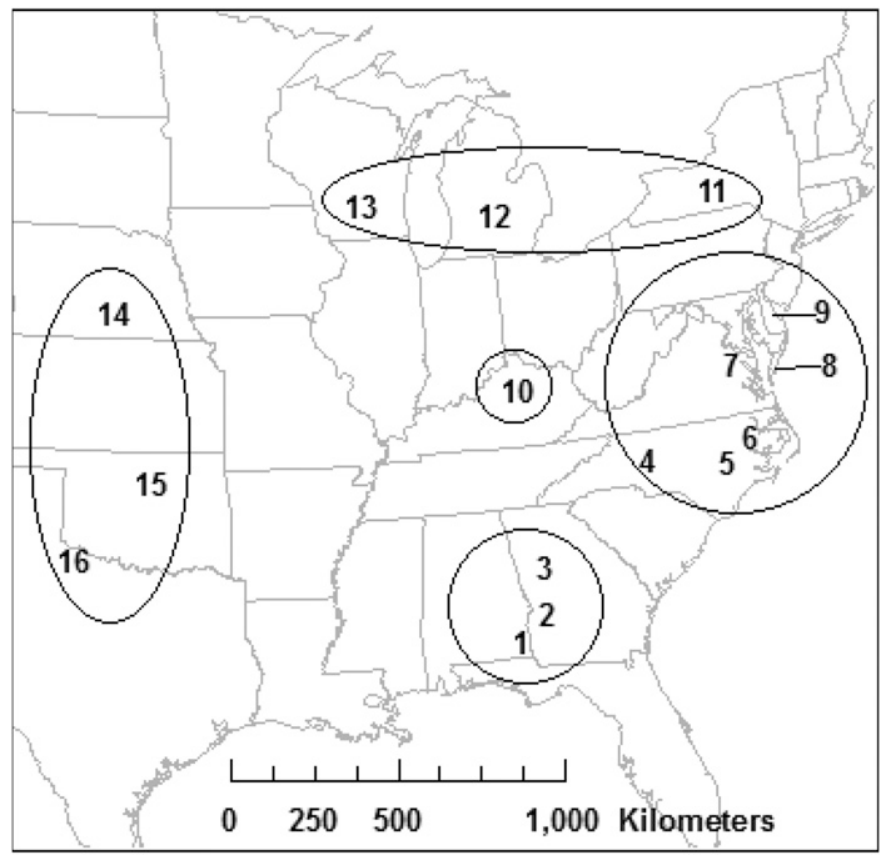

Fig. 1. U.S. locations from which samples of the wheat pathogen Blumeria graminis f. sp. tritici were derived for population structure study. The circles/ovals indicate geographic regions; collections from 2003 and/or 2005 were Southeast region (1, Headland, AL; 2, Plains, GA; and 3, Griffin, GA) and Mid-Atlantic region (4, Salisbury, NC; 5, Kinston, NC; 6, Chocowinity, NC; 7, Warsaw, VA; 8, Painter, VA; and 9, Felton, DE). Collections in 2007 or 2010: 10, Lexington, KY, Great Lakes region (11, Ithaca, NY; 12, Sandusky, MI; and 13, Arlington, WI) and Southern Plains region (14, Red Cloud, NE; 15, Stillwater, OK; and 16, Chillicothe, TX). and Bowen 1989). The powdery mildew population in the U.S. MidAtlantic region has been highly adaptable, and qualitative resistance has not remained effective for long in wheat cultivars widely grown in this region. For example, cultivars bearing Pml7 (Griffey et al. 2005a,b) had nearly complete resistance to powdery mildew when released in 2002 (Bowman 2004). However, by the spring of 2005, isolates virulent to Pm17 were sampled at low frequency in Alabama and Georgia (Parks et al. 2009). By 2009, Pm17 virulence was present at unusually high levels in Virginia (C. Griffey, personal communication) and also in North Carolina (Cowger et al. 2009).

An introduced pathogen with limited genetic diversity due to founder effects should not be highly adaptable, although multiple sequential introductions can mitigate the effects of genetic drift (Mack et al. 2002). One explanation for this pathogen's adaptability may be the high levels of TE activity, which are thought to provide functional, "tuning knob" variation (King 2011). TEs have been associated with SSR formation (Buschiazzo and Gemmell 2006), which could facilitate evolution, as SSRs are found both within and outside genes, including in introns and regulatory regions.

The current study had two main objectives. First, we sought to evaluate the distribution of presumptively neutral genetic variability across the main areas of the central and eastern United States where B. graminis f. sp. tritici occurs. Previously, only samples from the Mid-Atlantic and Southeastern United States had been assayed and only with SNP markers (Parks et al. 2009). The current study applied what we expected to be a more informative marker system to those regions, but also for the first time to regions north and west of the Appalachian Mountains, using polymorphic SSR markers and four polymorphic SNP loci. Based on the higher mutation rate of SSRs compared with SNPs, we expected to find a high level of SSR polymorphism, as well as greater haplotypic diversity. We also expected to find population differentiation, particularly between populations east and west of the Appalachian Mountains.

Second, we wanted to assess migration within the U.S. area where wheat powdery mildew epidemics occur. Our hypothesis was that the Appalachian Mountains served as a significant barrier to migration, both due to their physical elevation and also because wheat is not grown in or near them. Historically, wheat powdery mildew epidemics have been most frequent on the east side of the Appalachians, where mildew resistance is an important breeding objective, and less frequent on the west side, where mildew resistance is a lesser priority. We expected to find diminished or nonexistent migration across the mountains.

\section{MATERIALS AND METHODS}

Mildew isolate collection. Samples were collected from 16 locations in 12 states in 2003, 2005, 2007, or 2010, with two locations (Kinston, NC and Warsaw, VA) yielding samples in each of 2 years (Fig. 1; Table 1). For the most part, the sampled cultivars were susceptible or moderately susceptible to powdery mildew, although in a few cases cultivars possessed moderate levels of partial resistance (Table 1). Sample collection methods for isolates from Alabama, Delaware, Georgia, North Carolina, and Virginia were previously described (Parks et al. 2008, 2009). Briefly, in 2003 and 2005, samples were collected from senescing wheat plants bearing chasmothecia. Chasmothecial maturation was induced in the lab; ascospores were allowed to infect detached leaves of the wheat cultivar Chancellor, which has no genes effective against U.S. B. graminis f. sp. tritici isolates; and the resulting infections were subcultured using needles to ensure that only one genotype was present. Spores were washed from infected leaves with a solution of $90 \%$ ethanol, pelleted by centrifugation, air-dried, and frozen at $-20^{\circ} \mathrm{C}$ until DNA extraction.

Samples from Kentucky, Nebraska, Oklahoma, and Texas were collected in 2007, and those from New York, Michigan, and Wisconsin were collected in 2010. These samples were obtained as viable conidia on living wheat tissue. Samples of chasmothecia from Kentucky, Oklahoma, and Nebraska had been obtained in 
2003 and 2005, but numerous attempts to derive isolates failed to produce viable cultures. Thus, because of the difficulty and unreliability of maturing and hatching chasmothecia in the lab, and the greater ease of acquiring conidial samples from collaborators, all further isolates were created from conidia. These conidia were transferred by shaking infected leaves over detached leaves of mildew-susceptible cultivar Chancellor (CI 12333). Isolates were subcultured and spores were collected as described above.

DNA extraction and marker amplification. For isolates sampled in 2003 and 2005, DNA was extracted from conidia using a modified Qiagen DNeasy blood and tissue kit (Qiagen, Valencia, CA) (Parks et al. 2009). For samples collected after 2005, DNA was obtained using a modified CTAB protocol (Stein et al. 2001) as follows. Five-centimeter leaf sections of 10-day-old plants were placed in 2-ml screw-cap microcentrifuge tubes and frozen at $-20^{\circ} \mathrm{C}$ until DNA extraction. Cells were disrupted by adding eight nickelplated lead beads to the tube with leaf material, flash-freezing in liquid nitrogen, and vigorously shaking tissue on a vortex lysis adapter (Mo Bio, Carlsbad, CA) for 15 s. If tissue was not fully ground, tubes were refrozen in liquid nitrogen and ground an additional $15 \mathrm{~s}$. When lysis was sufficient, $600 \mu \mathrm{l}$ of CTAB extraction buffer (1\% [wt/vol] cetyltrimethylammonium bromide [CTAB], $0.7 \mathrm{M} \mathrm{NaCl}, 0.1 \mathrm{M}$ Tris/HCl, pH 7.5, $50 \mathrm{mM}$ EDTA, $\mathrm{pH}$ 8, and 1\% [vol/vol] $\beta$-mercaptoethanol) was added and samples were incubated at $65^{\circ} \mathrm{C}$. After $4 \mathrm{~h}$ incubation, $600 \mu \mathrm{l}$ of chloroform/isoamyl alcohol (24:1) was added to the lysis solution and gently mixed for $15 \mathrm{~min}$ on an inversion table at the lowest setting. Samples were centrifuged at
$10,000 \mathrm{rpm}$ for $8 \mathrm{~min}$, supernatant was transferred to a new microcentrifuge tube, and DNA was precipitated by adding $350 \mu \mathrm{l}$ of 2-propanol and inverting 10 times. Precipitated DNA was centrifuged for $8 \mathrm{~min}$ at 15,000 rpm and the resulting DNA pellet was washed with a solution of $76 \%$ ethanol and $200 \mathrm{mM}$ sodium acetate, followed by another wash with $76 \%$ ethanol. The clean pellet was air-dried and rehydrated using $100 \mu \mathrm{l}$ of TE buffer.

DNA sequence data for samples collected in 2003 and 2005 had been previously reported (Parks et al. 2009); unused DNA was maintained at $-80^{\circ} \mathrm{C}$, and then used for SSR marker amplification following published protocols (Parks et al. 2011). Polymerase chain reaction amplification of 10 SSR and four SNP markers for samples collected post-2005 was performed as previously described (Parks et al. 2009, 2011). SNPs were found at a total of nine variable sites in four genes (two to five sites per gene; Table 2). The SSR markers are species-specific, and reproducibly generate one band per isolate. A handful of isolates with more than one band were assumed to consist of more than one $B$ graminis f. sp. tritici genotype, and were not included. DNA sequencing and SSR fragment analysis were carried out by Eton Biosciences, Inc. (Research Triangle Park, NC). Sequences were manually aligned and edited using Sequencher 4.7 (Genecodes Corporation, Ann Arbor, MI).

SSR fragment sizing was performed using PeakScanner version 1.0 (Applied Biosystems, Carlsbad, CA). SSR fragment sizes were binned into discrete alleles following expected periodicity using TANDEM (Matschiner and Salzburger 2009). In the entire data set, three extreme allele values were deleted because the repeat numbers

TABLE 1. Locations, years, plots and cultivars from which samples of Blumeria graminis f. sp. tritici were collected

\begin{tabular}{|c|c|c|c|c|c|}
\hline \multirow[b]{2}{*}{ City, state } & \multirow[b]{2}{*}{ Year sampled ${ }^{\mathrm{a}}$} & \multirow[b]{2}{*}{ Location number (Fig. 1) } & \multirow[b]{2}{*}{ Plots sampled } & \multicolumn{2}{|l|}{ Cultivars sampled } \\
\hline & & & & Cultivar name (number of isolates) & $\begin{array}{l}\text { Susceptibility to } \\
\text { powdery mildew }^{\mathrm{b}}\end{array}$ \\
\hline Griffin, GA & 2003 & 3 & 2 & Coker 9663 (9) & $\mathrm{S}$ \\
\hline Salisbury, NC & 2003 & 4 & 3 & Coker 9663 (27) & $\mathrm{S}$ \\
\hline \multirow[t]{2}{*}{ Kinston, NC } & 2003 & 5 & 3 & Coker 9663 (24) & $\mathrm{S}$ \\
\hline & 2005 & & 3 & Roane (22) & $\mathrm{S}$ \\
\hline \multirow[t]{2}{*}{ Warsaw, VA } & 2003 & 7 & 2 & Coker 9663 (11) & $\mathrm{S}$ \\
\hline & 2005 & & 2 & Unknown susceptible line (7) & $\mathrm{S}$ \\
\hline Headland, AL & 2005 & 1 & 2 & GA951216-2E26 (9) & MR \\
\hline Plains, GA & 2005 & 2 & 2 & P26R61 (16) & MR \\
\hline Chocowinity, NC & 2005 & 6 & 1 & Roane (9) & $\mathrm{S}$ \\
\hline \multirow[t]{2}{*}{ Painter, VA } & 2005 & 8 & 1 & Roane (5) & $\mathrm{S}$ \\
\hline & 2005 & & 1 & Unknown susceptible bread wheat (8) & $\mathrm{S}$ \\
\hline Felton, DE & 2005 & 9 & 1 & Roane (10) & $\mathrm{S}$ \\
\hline \multirow[t]{2}{*}{ Lexington, KY } & 2007 & 10 & 1 & Becker (7) & $\mathrm{S}^{\mathrm{c}}$ \\
\hline & 2007 & & 1 & Jagalene (10) & S \\
\hline Red Cloud, NE & 2007 & 14 & 3 & Jagalene (6) & $\mathrm{S}$ \\
\hline \multirow[t]{6}{*}{ Stillwater, OK } & 2007 & 15 & 1 & JEI $110(4)$ & $?$ \\
\hline & 2007 & & 1 & $2145(3)$ & $\mathrm{S}$ \\
\hline & 2007 & & 1 & Danby (5) & $S$ \\
\hline & 2007 & & 1 & OK Bullet (4) & $\mathrm{S}$ \\
\hline & 2007 & & 1 & OK02522W (2) & $?$ \\
\hline & 2007 & & 1 & Overley (3) & $\mathrm{S}$ \\
\hline \multirow[t]{2}{*}{ Chillicothe, TX } & 2007 & 16 & 1 & TAMW-101 (5) & $S^{d}$ \\
\hline & 2007 & & 1 & Jagalene (4) & S \\
\hline \multirow[t]{4}{*}{ Ithaca, NY } & 2010 & 11 & 1 & Brundage 96 (3) & $?$ \\
\hline & 2010 & & 1 & Harus (3) & $\mathrm{MS}^{\mathrm{e}}$ \\
\hline & 2010 & & 1 & Madsen (1) & MS \\
\hline & 2010 & & 1 & Saranac (8) & MR \\
\hline Sandusky, MI & 2010 & 12 & 3 & Hopewell (7) & MR \\
\hline \multirow{4}{*}{ Arlington, WI } & 2010 & 13 & 1 & Hopewell (2) & MR \\
\hline & 2010 & & 1 & Red Ruby (2) & MS \\
\hline & 2010 & & 1 & Kaskaskia (1) & S \\
\hline & 2010 & & 1 & KW 62 (1) & MS \\
\hline
\end{tabular}

a Isolates derived in 2003 and 2005 were from chasmothecia; those from 2007 and 2010 were from conidia.

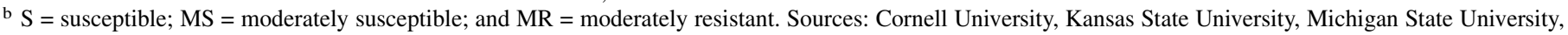
North Carolina State University, Ohio State University, Oklahoma State University, University of Georgia, University of Wisconsin, Washington Crop Improvement Association, authors' observations, and as further footnoted. ? = no information available.

c According to Liu et al. (2001).

d According to Worrall et al. (1995).

e According to Teich (1986). 
were so distant from others at that locus that they were suspected of resulting from chromosome rearrangement or experimental error.

Genetic diversity analysis. As B. graminis f. sp. tritici populations are strongly structured by sexual reproduction, haplotypes are often short-lived and recombined by sex, and there are no true races. Analysis of genetic diversity in this study was thus based on comparisons of allelic profiles of isolates, rather than genotype frequencies.

Nei's unbiased diversity was assessed by locus within populations, across loci for each population, and for the overall sample, using GenAlEx version 6.5. Allelic structure of populations based on SSR data was used for migration analysis and assessment of the probability for any specific population that it was in fact effectively random-mating. To evaluate allelic diversity using the SNP data, overall and per-location estimates of nucleotide diversity and Watterson's population mutation rate $(\Theta \mathrm{w})$ were calculated using DnaSP 5.10 (Librado and Rozas 2009).

In order to increase the statistical power of tests, locations were grouped into regions based on geographic proximity, as well as the prior finding of subdivision in the B. graminis $\mathrm{f}$. sp. tritici population between the Mid-Atlantic and Southeastern United States (Parks et al. 2009). The four initial regions chosen, and the locations comprising them as numbered in Figure 1, were as follows: the Southeast (SOE, 1 to 3), Mid-Atlantic (MID, 4 to 9), Great Lakes (GLK, 11 to 13), and the Southern Plains (SPL, 14 to16). Ithaca, NY (location 11) was approximately equidistant from the GLK and MID regions; isolates from Ithaca differed significantly in a Fisher's exact test from those in the MID $(P=0.0002)$ but not the GLK $(P=0.44)$, and thus Ithaca was assigned to the GLK region. Isolates from Lexington, KY (Location 10) did not fit into any of the four regions above $(P \leq 0.0001)$ and were considered to represent (albeit very partially) a fifth region.

Population differentiation and clustering. A principal coordinates analysis (PCoA) of pairwise genetic distances between populations was conducted using GenAlEx version 6.5 to assess patterns of clustering and differentiation among populations.

Isolation by distance was assessed for the SSR data using the Mantel test (Mantel 1967; Smouse and Long 1992) in GenAlEx version 6.5 (Peakall and Smouse 2006). Matrices were plotted with geographic distance on the $\mathrm{X}$ axis and Nei's genetic distance among locations on the Y axis. Potential correlation between the two data matrices was tested using 9,999 permutations of the data set under a null hypothesis of no correlation between genetic and geographic distance.

Linkage disequilibrium and random-mating. To evaluate potential deviations from random-mating, tests of linkage equilibrium were conducted on site-years (i.e., with Kinston and Warsaw samples included separately by year). SSR data were clone-corrected before multilocus associations were tested. For clone-correction, two isolates were considered to be clones if their SSR and SNP genotypes (and virulence profiles where available) were identical and they were sampled from the same location in the same year. This resulted in the omission for this analysis of a total of nine isolates: two from Lexington, one from Red Cloud, and six from Stillwater. There were three cases in which two isolates shared the same SSR-SNP genotype yet came from different locations, and they were considered not to be clones (Brewer et al. 2012).

Multilocus linkage disequilibrium (LD) was determined using MultiLocus v. 1.3b (Agapow and Burt 2001). The index of association $\left(\mathrm{I}_{\mathrm{A}}\right)$ and $\bar{r}_{d}$ were calculated, and their $P$ values were estimated by 1,000 random permutations of the data. The complete, 229-isolate clonecorrected sample was analyzed for LD. Separate LD analyses were also performed on the chasmothecial and conidial fractions of the total sample. Finally, LD was also analyzed separately for (i) the Lexington, Red Cloud, Stillwater, and Chillicothe locations (locations 10, 14, 15, and 16) that clustered separately in the PCoA analysis, and (ii) the remaining populations.

Migration. Directional gene flow (migration) was estimated using the SSR data. In order to assure adequate sample sizes, two hypotheses were tested that each involved separating the sample into two groups. For hypothesis 1, that the Appalachian Mountains form a significant barrier to migration, locations in Figure 1 were divided into groups east (locations 1 to 9) and west (locations 10 to 16) of the Appalachian Mountains. Hypothesis 2 relied upon the results of the PCoA clustering analysis for a somewhat different east-west partition of locations into these two groups: Lexington, Red Cloud, Stillwater, and Chillicothe (locations 10, 14, 15, and 16) versus all other locations. For each hypothesis, four models were tested: unidirectional (asymmetric) migration in each direction; two-way migration; and panmixia.

In both hypotheses, the western sample was two to three times smaller than the eastern sample. To address this problem, a random selection was made from each eastern location of 10 and 5 isolates for the first and second hypotheses, respectively. Isolates with more than one missing value were passed over in randomized order. This

TABLE 2. Distribution of Blumeria graminis f. sp. tritici single nucleotide polymorphism haplotypes by geographic region of the United States ${ }^{\mathrm{a}}$

\begin{tabular}{|c|c|c|c|c|c|c|c|c|c|c|c|c|c|c|c|}
\hline \multirow[b]{3}{*}{ Haplotype } & \multirow{3}{*}{$\frac{\mathrm{AOX}}{\mathrm{C}}$} & \multicolumn{3}{|c|}{ PKA } & \multicolumn{3}{|c|}{ PPA } & \multicolumn{2}{|c|}{ TUB } & & & & & & \\
\hline & & \multirow{2}{*}{$\begin{array}{l}\overline{\mathrm{A}} \\
\overline{\mathrm{i}}\end{array}$} & \multirow{2}{*}{$\frac{G}{-}$} & \multirow{2}{*}{$\frac{\mathrm{T}}{\mathrm{i}}$} & \multirow{2}{*}{$\begin{array}{l}\overline{\mathrm{C}} \\
\overline{\mathrm{i}}\end{array}$} & \multirow{2}{*}{$\frac{\mathrm{T}}{\mathrm{i}}$} & \multirow{2}{*}{$\begin{array}{l}\frac{\mathrm{C}}{-} \\
-\end{array}$} & \multirow{2}{*}{$\frac{\overline{\mathrm{T}}}{\overline{\mathrm{i}}}$} & \multirow{2}{*}{$\frac{\mathrm{C}}{\mathrm{i}}$} & \multicolumn{6}{|c|}{ Number of isolates ${ }^{b}$} \\
\hline & & & & & & & & & & MID & GLK & SPL & SOE & $\mathrm{KY}$ & Total \\
\hline $\mathrm{H} 1$ & . & . & . & A & . & . & . & . & . & 18 & 12 & 2 & 20 & 3 & 55 \\
\hline H6 & . & . & . & . & . & . & . & $\mathrm{C}$ & . & 8 & 1 & 2 & & & 11 \\
\hline H11 & . & 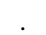 & 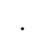 & 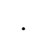 & . & . & . & . & $\mathrm{G}$ & 7 & & & & & 7 \\
\hline $\mathrm{H} 14$ & . & . & . & A & 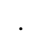 & 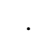 & . & $\dot{\mathrm{C}}$ & . & 5 & & & 4 & & 9 \\
\hline H12 & . & . & . & A & $\mathrm{T}$ & $\mathrm{C}$ & . & . & . & 1 & & 1 & & & 2 \\
\hline $\mathrm{H} 4$ & . & $\mathrm{T}$ & . & . & & . & . & 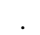 & . & 1 & & & & & 1 \\
\hline H8 & . & . & . & . & $\mathrm{T}$ & . & . & C & . & 1 & & & & & 1 \\
\hline H9 & . & . & . & . & $\mathrm{T}$ & . & . & . & $\mathrm{G}$ & 1 & & & & & 1 \\
\hline H5 & . & . & $\mathrm{T}$ & & & & . & . & . & & 1 & & & & 1 \\
\hline $\mathrm{H} 13$ & . & . & . & A & $\mathrm{T}$ & $\mathrm{C}$ & A & $\mathrm{C}$ & . & & & & 1 & & 1 \\
\hline $\mathrm{H} 3$ & . & $\mathrm{T}$ & . & . & . & . & . & $\mathrm{C}$ & . & & & 1 & & & 1 \\
\hline
\end{tabular}

a $\mathrm{AOX}=$ alpha oxidase, $\mathrm{PKA}=$ protein kinase $\mathrm{A}, \mathrm{PPA}=$ protein phosphatase type $2 \mathrm{~A}$, and $\mathrm{TUB}=\beta$-tubulin; $\mathrm{i}=$ phylogenetically informative and $-=$ uninformative. Consensus nucleotides are given just below gene names.

b Collections in 2003 and/or 2005: Mid-Atlantic (MID) region (Salisbury, NC; Kinston, NC; Chocowinity, NC; Warsaw, VA; Painter, VA; and Felton, DE) and Southeast (SOE) region (Headland, AL; Plains, GA; and Griffin, GA). Collections in 2007 or 2010: Lexington, KY; Great Lakes (GLK) region (Ithaca, NY; Sandusky, MI; and Arlington, WI) and Southern Plains (SPL) region (Red Cloud, NE; Stillwater, OK; and Chillicothe, TX). 
selection brought the east/west ratios of isolates to $81 / 87$ and 53/60 for hypothesis 1 and hypothesis 2 , respectively. To test the repeatability of the analysis, migration in both directions was evaluated three times, each with its own sample selected randomly as just described, for each hypothesis.

Migrate-N uses a coalescent approach to estimate theta $(\Theta)$, the mutation-scaled effective population size, and $M$, the mutationscaled effective immigration rate. For haploids, $\Theta=2 N_{e} \mu$, where $2 N_{e}$ is the effective population size and $\mu$ is the mutation rate per marker per generation. Parameter $M$ is a ratio of immigration to mutation $(\mathrm{m} / \mu$, where $m$ is the immigration rate per generation from a source to a sink population). Multiplication of estimates $\Theta$ and $M$ (and division by 2 for a haploid organism) provides a per-generation estimate of the number of immigrants between two populations. Comparisons of models were performed via ratios of marginal likelihoods (Bayes factors), using the Bezier approximation score to calculate model probabilities (Beerli and Palczewski 2010).

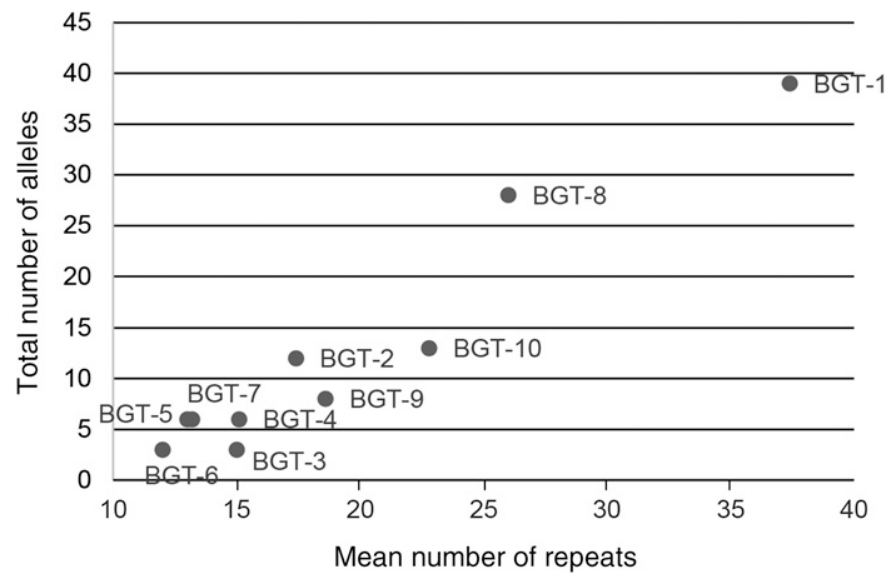

Fig. 2. Mean number of simple sequence repeats, averaged across $238 \mathrm{Blu}$ meria graminis $\mathrm{f}$. sp. tritici isolates, plotted against the total number of simple sequence repeat alleles at each locus.
Migrate-N analyses employed the Bayesian search strategy with 10 independent replications. Starting parameters for analysis were derived from $\mathrm{F}_{\mathrm{ST}}$, and all loci were assumed to have a constant mutation rate. To evaluate more genealogies, a static heating scheme with four temperatures of $1,000,000,3,1.5$, and 1 was used, as recommended in the Migrate- $\mathrm{N}$ manual. Runs included a burn-in of 50,000 steps to avoid biasing the results based on the starting parameter. After the burn-in, 10,000 steps were recorded at intervals of 50 steps. Uniform prior distributions of $\Theta$ and $M$ were restricted to the ranges of 0 to 70 and 0 to 300 , respectively. Short preliminary runs (data not shown) determined appropriate prior boundaries.

\section{RESULTS}

In total, 238 B. graminis f. sp. tritici isolates were evaluated: 71 isolates collected from four locations in 2003, 86 from seven locations in 2005, 53 from four locations in 2007, and 28 from three locations in 2010 (Table 1). The sample sizes evaluated with SSR markers were different from those analyzed with SNPs due to DNA availability and quality, with 238 individuals genotyped for SSRs and 216 for SNPs.

Allelic diversity. Among the 10 SSR loci, allelic diversity differed considerably (Fig. 2). The loci BGT-1 and BGT-8 were highly polymorphic, with 39 and 28 alleles detected, respectively (after deletion of three out-of-range values, as explained above). At the other extreme, only three alleles each were found at BGT-3 and BGT-6, with most locations having only one or two alleles. Across locations and loci, there was a mean of 12.4 alleles per locus $\left(\mathrm{N}_{\mathrm{a}}\right)$. By location, mean $\mathrm{N}_{\mathrm{a}}$ values were positively associated with sample sizes $(P<0.05$ by least-squares regression); however, relative to their sample sizes, Plains (GA) and Chocowinity (NC) had low mean $\mathrm{N}_{\mathrm{a}}$ values (3.0 and 2.2, respectively), and Ithaca (NY) had a high value (4.9). There was a significant correlation between mean number of repeats, when simply averaged across the 238 isolates, and total number of alleles detected in all isolates (Fig. 2).

A moderate degree of genetic diversity was found within populations (Table 3). The overall mean of population diversities, weighted by sample size, was 0.494 (out of a maximum of 1.0).

TABLE 3. Genetic diversity of 238 Blumeria graminis f. sp. tritici isolates derived from 16 U.S. locations (18 site-years) in 2003, 2005, 2007, and 2010 and genotyped at 10 simple sequence repeat loci

\begin{tabular}{lcccc}
\hline Location & Number of isolates & Number of haplotypes & Number of alleles at locus $\left(\mathrm{N}_{\mathrm{a}}\right)^{\mathrm{b}}$ & $\begin{array}{c}\text { Diversity within } \\
\text { populations }^{\mathrm{c}}\end{array}$ \\
\hline Hea (1) & 9 & 8 & $2.5(0.40)$ & $0.415(0.096)$ \\
Pla (2) & 16 & 15 & $3.0(0.45)$ & $0.431(0.079)$ \\
Gri (3) & 9 & 8 & $2.4(0.31)$ & $0.416(0.086)$ \\
Sal (4) & 27 & 26 & $5.4(1.15)$ & $0.528(0.103)$ \\
Kin03 (5) & 24 & 24 & $5.8(1.32)$ & $0.539(0.106)$ \\
Kin05 (5) & 22 & 22 & $5.0(1.33)$ & $0.524(0.104)$ \\
Cho (6) & 9 & 8 & $2.2(0.33)$ & $0.383(0.099)$ \\
War03 (7) & 11 & 10 & $3.3(0.60)$ & $0.515(0.090)$ \\
War05 (7) & 7 & 7 & $2.7(0.45)$ & $0.492(0.097)$ \\
Pai (8) & 13 & 12 & $3.5(0.81)$ & $0.499(0.109)$ \\
Fel (9) & 10 & 10 & $3.3(0.60)$ & $0.538(0.095)$ \\
Lex (10) & 17 & 12 & $3.9(0.82)$ & $0.536(0.107)$ \\
Ith (11) & 15 & 15 & $4.9(0.92)$ & $0.583(0.103)$ \\
San (12) & 7 & 7 & $2.9(0.64)$ & $0.512(0.108)$ \\
Arl (13) & 6 & 6 & $2.6(0.52)$ & $0.443(0.122)$ \\
Red (14) & 6 & 5 & $2.5(0.48)$ & $0.463(0.134)$ \\
Sti (15) & 21 & 12 & $3.7(0.75)$ & $0.472(0.092)$ \\
Chi (16) & 9 & 9 & $3.1(0.43)$ & $0.594(0.088)$ \\
Mean & & & $3.5(0.47)$ & \\
Total ${ }^{\text {d }}$ & 238 & 210 & & $0.494(0.023)$ \\
\hline
\end{tabular}

a Number in parentheses = location number in Figure 1. Ascosporic samples obtained from locations 1 to 9 in 2003 and/or 2005, and conidial samples from locations 10 to 16 in 2007 or 2010.

b Mean number of alleles across loci; standard error in parentheses.

c Nei's unbiased genetic diversity by population, followed by the mean across loci and populations; standard errors in parentheses.

d Total number of isolates and number of different haplotypes in the total 238-isolate sample (not the sum of per-location values). 
With regard to the diversity of individual populations, Chocowinity with 0.383 was significantly less diverse than Chillicothe with 0.594 , but most populations did not differ significantly from each other in diversity $(P \leq 0.05)$.

There was no regional clustering of either low- or high-diversity populations. Mean diversity values for the regions were $\mathrm{SOE}=0.42$, $\mathrm{GLK}=0.51, \mathrm{SPL}=0.51, \mathrm{MID}=0.50$, and $\mathrm{KEN}=0.54$. Similarly, chasmothecial populations did not have higher genetic diversity than conidial populations; mean values were 0.48 and 0.51 , respectively.

With respect to the DNA sequence data, calculated across all four SNP loci, nucleotide per-site diversity varied from 0.00035 in Stillwater (OK) to 0.00111 in Chillicothe (TX), with a mean of 0.00084 (Table 4). As expected, Watterson's joint estimator of mutation rate and population size $\left(\Theta_{\mathrm{w}}\right)$ corresponded well to SNP nucleotide diversity (Table 4); locations with lower nucleotide diversity had a lower $\Theta_{w}$. The $\Theta_{w}$ values ranged from 0.408 in Arlington (WI) to 1.663 in Sandusky (MI). Private SNP alleles in the European and Israeli samples studied previously in comparison with the smaller U.S. B. graminis f. sp. tritici sample (Parks et al. 2009) were also not found in the present, larger U.S. population.

A few locations had low genetic diversity based on both SSRs and SNPs: Arlington, (WI), Headland (AL), and Chocowinity (NC). Warsaw 2003 and Kinston (both years) had high values of both measures. But locations with intermediate SSR-based diversity had either high or low SNP-based diversity, and sample size was not associated with either.

Population diversity and structure. Based on the SSR data, genotypic diversity was extremely high, with 210 haplotypes identified in the total sample (Table 3 ). No haplotype was shared by more than three isolates (data not shown). In eight of the site-years, every isolate had a unique SSR haplotype (Table 3). Among the 21 isolates (15 after clone-correction) in the Stillwater, OK, population, there were 12 haplotypes.

Overall differentiation among populations and among regions was extremely high $(P<0.001$ in both cases). Locations clustered by geographic region (Fig. 3). The Mid-Atlantic and Great Lakes regions formed a single, loose cluster; the three Southeast locations also formed a cluster; and Kentucky clustered loosely with the Southern Plains locations. The 2003 and 2005 Kinston populations were tightly clustered with each other, as were the 2003 and 2005 Warsaw populations.
A significant positive association between Nei's genetic distance and geographic distance was found (Mantel test, $R^{2}=0.25, P=0.001$, Figure 4). This provided evidence of relatively weak isolation by distance; i.e., about $50 \%$ of the variation in genetic difference among populations could be explained by their physical separation.

Sexual recombination and $L D$. There was no significant LD in the chasmothecial populations sampled in 2003 and $2005\left(\bar{r}_{d}=\right.$ $0.001, P=0.357$ ), but LD was significant in the 72 isolates sampled as conidia in 2007 and $2010\left(\bar{r}_{d}=0.041, P=0.001\right.$, Table 5). In the same vein, the populations from Chillicothe, Lexington, Stillwater, and Red Cloud that clustered separately from other locations (Fig. 3) exhibited significant $\operatorname{LD}\left(\bar{r}_{d}=0.058, P<0.001\right)$, while the remaining locations did not $\left(\bar{r}_{d}=0.006, P=0.19\right)$. LD was not significant in the total clone-corrected sample of 229 isolates $\left(\overline{r_{d}}=0.01, P=0.10\right)$.

Migration. The migration analysis discarded models of twoway migration and panmixia for both hypotheses (Table 6). When populations were divided into groups east and west of the Appalachians, the western group had a larger effective population size $(\Theta)$. The

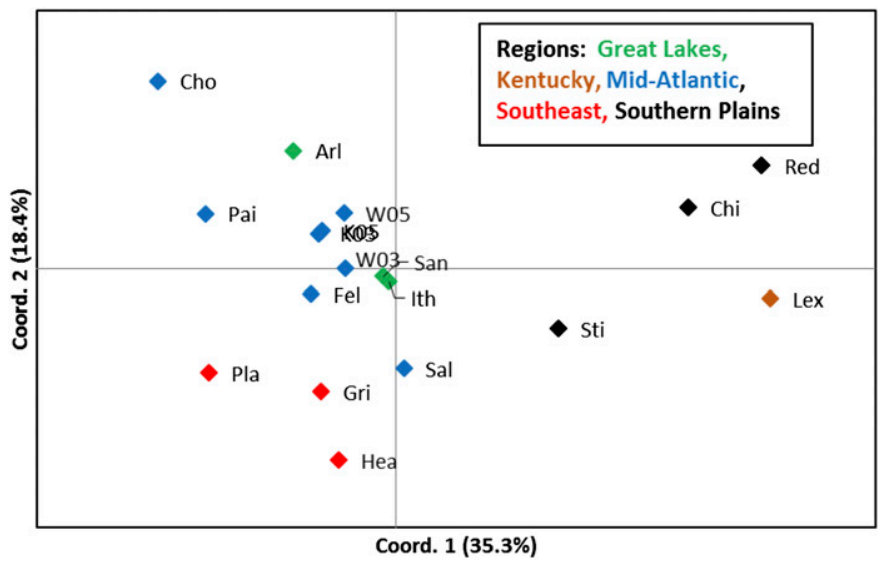

Fig. 3. Principal coordinates analysis of genetic clustering based on simple sequence repeat data from 10 loci in 238 isolates of the wheat pathogen Blumeria graminis f. sp. tritici. Collections in 2003 and/or 2005: Sal = Salisbury, NC; K03 and K05 = Kinston, NC in 2003 and 2005; Cho = Chocowinity, NC; W03 and W05 = Warsaw, VA in 2003 and 2005; Pai = Painter, VA; Fel = Felton, DE; Hea = Headland, AL; Pla = Plains, GA; and Gri = Griffin, GA. Collections in 2007 or 2010: Lex = Lexington, KY; Ith = Ithaca, NY; San = Sandusky, MI; Arl = Arlington, WI; Red = Red Cloud, NE; Sti $=$ Stillwater, $\mathrm{OK}$; and $\mathrm{Chi}=$ Chillicothe, $\mathrm{TX}$.

TABLE 4. Allelic diversity and number of haplotypes of 216 Blumeria graminis f. sp. tritici isolates from 16 U.S. locations, using single nucleotide polymorphism markers

\begin{tabular}{|c|c|c|c|c|}
\hline Location $^{\mathrm{a}}$ & Number of isolates & Nucleotide diversity (per site) ${ }^{\mathrm{b}}$ & $\Theta_{w}{ }^{c}$ & Number of haplotypes \\
\hline Hea (1) & 5 & 0.00031 & 0.480 & 2 \\
\hline $\mathrm{Pla}(2)$ & 13 & 0.00075 & 1.289 & 3 \\
\hline Gri (3) & 12 & 0.00061 & 0.662 & 3 \\
\hline Kin (5) & 41 & 0.00089 & 1.402 & 9 \\
\hline Cho (6) & 8 & 0.00038 & 0.771 & 2 \\
\hline War (7) & 13 & 0.00095 & 1.289 & 7 \\
\hline Pai (8) & 8 & 0.00074 & 0.771 & 3 \\
\hline Ith (11) & 15 & 0.00085 & 1.230 & 4 \\
\hline San (12) & 7 & 0.00110 & 1.633 & 4 \\
\hline Arl (13) & 7 & 0.00044 & 0.408 & 2 \\
\hline Red (14) & 5 & 0.00092 & 1.440 & 2 \\
\hline Sti (15) & 21 & 0.00035 & 0.834 & 4 \\
\hline Chi (16) & 9 & 0.00111 & 1.472 & 3 \\
\hline Total & 216 & 0.00084 & 1.513 & 15 \\
\hline
\end{tabular}

${ }^{a}$ Number in parentheses = location number in Figure 1. Ascosporic samples obtained from locations 1 to 9 in 2003 and/or 2005, and conidial samples from locations 10 to 16 in 2007 or 2010.

b Calculated with Jukes and Cantor correction (estimated using DNAsP).

c Watterson's population mutation rate per sequence (estimated using DNAsP). 
direction of migration was west to east at a rate of approximately five migrants per generation. In the three replicate tests of west-to-east versus east-to-west, where each replicate involved random isolate picks to make the samples closer in size, the west-to-east model was always selected.

When populations were divided for migration analysis on the basis of the clustering results (Fig. 3) into a west-central group (KY, $\mathrm{NE}, \mathrm{OK}$, and TX) versus all other locations, the west-central group also had a larger effective population size (Table 6). Again, the direction of migration was from the west-central group toward the other locations, this time at a rate of approximately two migrants per generation. In this case, the west-to-east migration was selected over the east-to-west alternative in two of the three replicate comparisons. For both hypotheses, a $P$ value of nearly 1.0 was associated with the best-fitting model.

\section{DISCUSSION}

This is the first reported population genetic analysis using neutral molecular markers on a sample of the $B$. graminis f. sp. tritici population in wheat powdery mildew-prone areas across the central and eastern United States. In broad strokes, the analysis revealed a population with high genetic and genotypic diversity, discernibly isolated by geographic distance. The most surprising finding was that the significant signal of migration within the overall population was from the region in which wheat powdery mildew is an episodic problem (the Southern Great Plains) to the region in which it occurs more regularly (the eastern United States), instead of the other way around.

Mean estimates of genic diversity in the U.S. B. graminis f. sp. tritici population were substantially higher using SSR markers than SNPs. This is unsurprising, since the mutation rate of SNPs is generally lower than those of SSRs.

SSR allelic diversity on a per-locus basis was in line with that reported for other plant-pathogenic fungi. For comparison, $\mathrm{N}_{\mathrm{a}}$ was two to four, with an average of 2.3, across nine SSR loci in 12 Zymoseptoria graminicola isolates (Owen et al. 1998), two to nine per locus (average $=3.8$ ) across 18 loci in 21 Puccinia triticina isolates (Szabo 2007), and 1.3 to 4.5 across eight SSR loci in 111 isolates of B. graminis f. sp. hordei (Tucker et al. 2014).

Given the high level of genomic rearrangement and TE activity previously demonstrated for this pathogen, we were surprised at the wide variation in per-locus SSR polymorphism, and the low levels of polymorphism detected at several loci. It is of course unknown whether any of the polymorphisms appeared recently, i.e., since the presumed introduction of the pathogen to the United States by European colonists, or more anciently.

The low diversity found at certain SSR loci could be accounted for by association with loci that are under selection in $B$. graminis f. sp. tritici, such as elicitors. Surveys of virulence frequencies have found that some virulence alleles are essentially fixed in the U.S. B. graminis f. sp. tritici population (e.g., virulence to $P m 3 a, P m 3 c$, Pm3f, Pm5a, Pm6, and Pm7 (Niewoehner and Leath 1998; Parks et al. 2008). On the other hand, frequencies of $B$. graminis f. sp.tritici virulence to other $P m$ genes (e.g., $P m 2, P m 4 b$ ) are intermediate (Niewoehner and Leath 1998; Parks et al. 2008), suggesting a role for balancing selection in structuring the population. If mutations to virulence at a locus have a deleterious effect on the pathogen and cultivars possessing that resistance are grown only sporadically, selection and drift may have reached an equilibrium, maintaining a low or moderate frequency of these alleles in the population. It is also possible that the locus is evolutionarily young, and greater polymorphism has not yet had time to appear.

Another factor potentially associated with the differences in diversity at SSR loci is repeat number. Mean fragment size per locus was correlated with mean $\mathrm{N}_{\mathrm{a}}$. Longer microsatellite alleles are more mutable than shorter alleles (Dettman and Taylor 2004). That is, long uninterrupted series of repeats have higher mutation rates than do short series, and are therefore more polymorphic (Buschiazzo and Gemmell 2006). Of course, other factors could also account for low allelic diversity, such as position of a locus on a chromosome.

It is interesting that genetic diversity estimates did not appear to vary according to whether samples were derived from conidia collected in the middle of a growing season, while plants are green, or from ascospores derived from senescent leaves collected at the end of the season. This suggests that selective forces during the growing season are not causing major bottlenecks that reduce diversity. Susceptible reservoirs may explain this outcome, as our samples mainly came from susceptible cultivars with no known effective resistance genes. Of course, bottlenecks are rare where resistant cultivars are only occasionally grown.

Even though genetic diversity did not differ between chasmothecial and conidial populations, the populations sampled from conidia exhibited significant linkage disequilibrium, while those originating from chasmothecia did not. LD is not expected when using neutral markers to assay populations that are undergoing regular sexual reproduction. The pooling of previously isolated, genetically

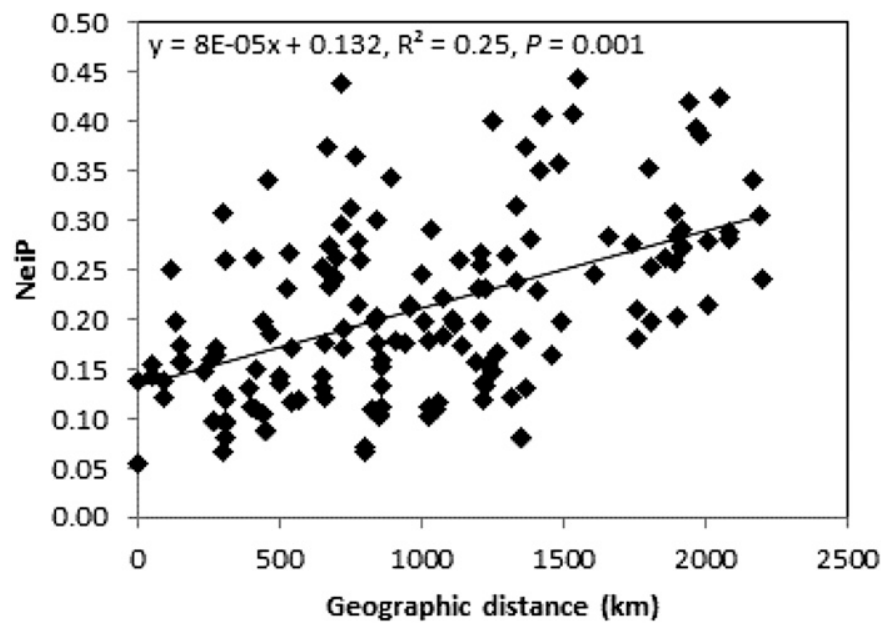

Fig. 4. Plot of Nei's genetic distance versus geographic distance, using simple sequence repeat markers from 238 isolates of the wheat pathogen Blumeria graminis f. sp. tritici originating from 16 locations in 12 U.S. states in 2003, 2005, 2007, and 2010. Geographic regions: Great Lakes, Kentucky, MidAtlantic, Southeast, and Southern Plains.

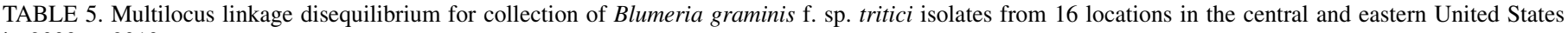
in 2003 to 2010

\begin{tabular}{|c|c|c|c|}
\hline Population $^{\mathrm{a}}$ & Sample size ${ }^{b}$ & $\mathrm{I}_{\mathrm{A}}(P$ value $)$ & $\bar{r}_{d}(P$ value $)$ \\
\hline Chasmothecial populations & 157 & $0.008(0.357)$ & $0.001(0.357)$ \\
\hline Conidial populations & 72 & $0.338(0.001)$ & $0.041(0.001)$ \\
\hline Chillicothe, Lexington, Red Cloud, Stillwater & 44 & $0.454(<0.001)$ & $0.058(<0.001)$ \\
\hline All other locations & 185 & $0.054(0.192)$ & $0.006(0.192)$ \\
\hline Total sample & 229 & $0.083(0.074)$ & $0.010(0.101)$ \\
\hline
\end{tabular}

a Figure 1 and Table 3 provide chasmothecial and conidial populations.

b Original population of 238 was clone-corrected and nine isolates were omitted. 
different populations could have led to a spurious detection of LD in the conidial populations(Wolfe and Knott 1982). This would be consistent with our finding of isolation by distance, although it is noteworthy that LD was not found in the Mid-Atlantic and Southeast samples. The LD observed in the conidial populations may be the result of multiple cycles of asexual reproduction during the growing season, as was found with Erysiphe necator, the grape powdery mildew pathogen (Brewer et al. 2012). We also considered as a possibility that $B$. graminis $\mathrm{f}$. sp. tritici populations were not maturing their ascospores in Great Plains conditions. However, in that case wheat powdery mildew epidemics would have to be significantly initiated by conidia and mycelium that oversummered in the hot, arid conditions of Oklahoma and Texas, which seems unlikely. Epistatic selection was also suggested as the explanation for LD in B. graminis f. sp. hordei (Brown and Wolfe 1990). While this cannot be ruled out here, it seems more likely the life stage sampled helps explain why we found LD in the populations derived from conidia.

Haplotypic diversity based on the 10 SSR markers was very high: 210 haplotypes among 238 isolates, with every isolate having a unique haplotype in eight of the site-years. Such high haplotypic diversity emanating from one or a few research plots per location reflects that this pathogen has an enormous effective population size and engages in frequent sexual recombination. This finding is in line with the work of O'Hara and Brown (1997), who found that in samples of 72 to 250 B. graminis f. sp. horde $i$ isolates from $100-\mathrm{m}^{2}$ barley plots, virulence pathotypes were usually found only once per plot. It is also similar to the report of Tucker et al. (2014) on B. graminis f. sp. hordei in Australia; they found 97 unique haplotypes in 111 B. graminis f. sp. hordei isolates analyzed with eight SSR loci. A large amount of $B$. graminis genetic variability can be sampled within a small spatial area, likely due to the establishment of local epidemics by large, airborne and atmospherically mixed populations.

The relatively small number of SSR genotypes at Stillwater (OK) was noteworthy given that those isolates originated from six different plots, a relatively large number in this experiment. The $B$. graminis f. $\mathrm{sp}$. tritici population may have undergone a bottleneck at this location, and this is consistent with a report that Pm3a was still effective there in 2009 (Chen et al. 2009), while it has not been effective east of the Appalachians since the 1990s (Niewoehner and Leath 1998). Oklahoma wheat powdery mildew populations may be isolated due to genetic drift from a founder effect that is too recent to be detected using SNP markers.

Despite the general correlation of geographic and genetic distance, the Great Lakes and Mid-Atlantic regions formed a genetically similar cluster, if a loose one. This suggests a history of gene flow between those regions. The Southeastern locations were grouped nearby, slightly separated from the GLK and MID regions. In all these locations, wheat powdery mildew is commonly seen, although it is less often severe outside the Mid-Atlantic states of North Carolina, Virginia, Maryland, and Delaware. The genetic similarity of the GLK and MID locations, despite the samples having been collected as much as seven years apart, indicates that it is appropriate to evaluate such questions as migration using an overall population in which subpopulations were collected in different years.

While Kentucky and the Southern Plains clustered separately, the three Southern Plains locations did not form a tight cluster, with the population from Stillwater, OK, being more remote. In these location west of the Appalachians Mountains, wheat powdery mildew appears more infrequently, which allows for bottlenecks and genetic isolation.

Within the individual MID locations Kinston (NC) and Warsaw (VA), in the heart of the U.S. region where B. graminis f. sp. tritici epidemics are most frequently severe, no differences were observed between 2003 and 2005 populations. Within these two locations, populations maintained their genetic makeup over this 2-year period. In the United States, there have not been detailed observations of where wheat powdery mildew survives year-round. Our finding is consistent with annual re-establishment from local sources. The lack of differentiation of Kinston or Warsaw populations over a 2-year period suggests that at least in the more conducive areas, populations survive year-to-year without detectable genetic drift.

This first assessment of migration in the U.S. B. graminis f. sp. tritici population yielded a surprising result: migration was detected from Great Plains locations and the centrally located state of Kentucky toward the north, south, and east, rather than from the mildew-prone Atlantic states toward the west. Our initial hypothesis that the Appalachian Mountains form a barrier to migration was confirmed for east-to-west migration, but not for west-to-east migration. The migration out of the Great Plains that we detected does fit with the fact that Pm3a, a gene widely deployed in the 1980s in the eastern United States, was defeated there by the early 1990s but remains effective in Oklahoma (Chen et al. 2009; C. Cowger, unpublished data). The finding of a larger effective population in the west may reflect the larger wheat area there, and also the greater genetic drift associated with frequent extinction and recolonization in a less conducive physical environment.

Prevailing wind directions in the United States in the months November through May, when B. graminis f. sp. tritici infections occur, are a likely reason for our migration results. Winds in the

TABLE 6. Evidence of west-to-east migration from a set of 238 Blumeria graminis f. sp. tritici isolates collected from 16 U.S. locations in 2003, 2005, 2007, and 2010

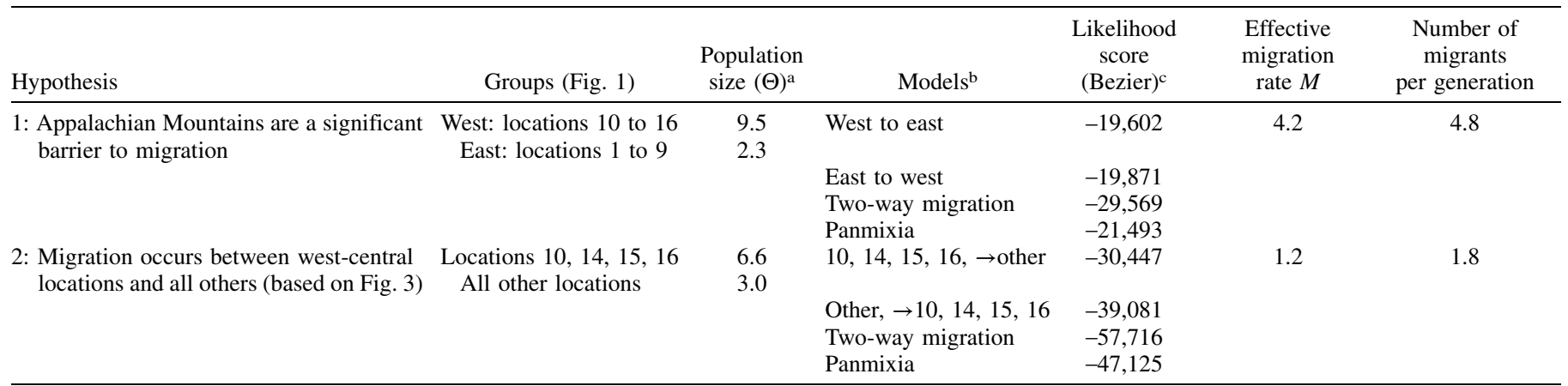

\footnotetext{
a Mutation-scaled effective population size.

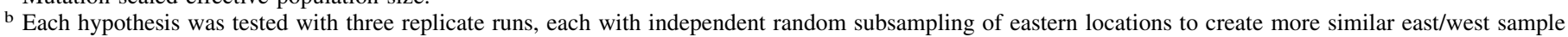
ratios (see text for details). Likelihood scores for first two models are means of three replicates, while two-way migration and panmixia scores are from one replicate each. $M$ and number of migrants per generation are also means of three replicates.

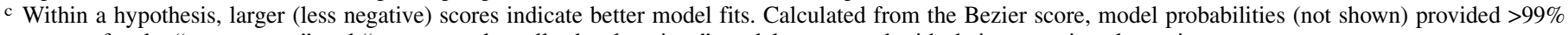
support for the "west-to-east" and "west-central to all other locations" models compared with their respective alternatives.
} 
Southern and Central Plains are largely from south to north (Climate Atlas of the United States 2015). In Kentucky and the Great Lakes, Mid-Atlantic, and Southeast regions, winds are primarily toward the north and east. Thus, wind direction likely helps account for the fact that migration only from the Plains and Kentucky toward the north and east was detected.

The U.S. B. graminis f. sp. tritici population is not panmictic, given the clustering and isolation by distance. It appears to consist of a set of discrete, overlapping subpopulations that oversummer locally. Thus, while there is interregional migration and there may be LDD events, annual population establishment in the United States likely occurs primarily from relatively local sources. This contrasts with the annual interregional extinction-recolonization cycles of other obligate biotrophic fungal pathogens. For example, the wheat rusts (Puccinia triticina and Puccinia striiformis) recolonize in the United States, India, and elsewhere annually via south-to-north wind dispersion, including long-distance spore transport (Brown and Hovmøller 2002; Kolmer 2005; Nagarajan and Singh 1990). Wheat leaf rust overwinters in the southern United States and Mexico, and the urediniospores arrive by wind in the wheat production areas of the Great Plains and the eastern United States (Kolmer 2005). Similarly, the downy mildews, another important group of obligate pathogens, regularly undergo extinction and "green-wave" recolonization. Cucurbit downy mildew (caused by Pseudoperonospora cubensis) is annually extinguished in the north-central and eastern United States and recolonized from below the 30th latitude (Holmes et al. 2004). Similarly, tobacco blue mold, the downy mildew caused by Peronospora tabacina, does not overwinter in northern growing regions such as Connecticut and Massachusetts, but rather is reintroduced each season from its southern range, following the green wave of tobacco north at a mean rate of 9 to $18 \mathrm{~km} /$ day (Aylor 1999, 2003). Our evidence suggests that $B$. graminis f. sp. tritici is different. Borrowing the metaphor of Brown and Hovmøller (2002), if the rusts and downy mildews are like migratory birds among biotrophic plant pathogens, U.S. cereal powdery mildew is a less nomadic, more year-round resident.

On the other hand, SSR alleles were not specific to geographic region, as would be expected if the population were strongly differentiated and shaped by drift. A possible explanation for this is that the allelic variation predates a single introduction or a small set of introductions of a genetically well-mixed founding B. graminis $\mathrm{f}$. sp. tritici population by European colonists in the 17 th and 18 th centuries. In an alternative scenario, multiple founding populations were genetically distinct, but in the ensuing several hundred years, levels of gene flow among U.S. regions were sufficient to assure broad distribution of SSR allelic variation.

In conclusion, our study revealed a highly genetically diverse U.S. B. graminis f. sp. tritici population, in keeping with the huge population sizes, mixed reproductive mode, and enormous genomic plasticity of this parasite. Isolation by distance implies that populations are rekindled from relatively local sources, and is consistent with the model of a large, overlapping mosaic of local populations. This is not inconsistent with an important role for LDD. Indeed, while separation of populations east and west of the Appalachians was apparent, migration from the Southern Plains and Kentucky to the north, south and east was detected. These results suggest that novel virulences that arise anywhere along the eastern seaboard are likely to spread in that region and to the Great Lakes, but are not likely to appear in the Southern Plains nor elsewhere west of the Appalachians.

\section{ACKNOWLEDGMENTS}

We thank P. Beerli for consultation and especially P. Labadie for a large contribution to the Migrate analyses. We appreciate the technical assistance of M. Hargrove, M. Gromlich, and J. Essic. We also thank the contributors of mildew-infected wheat samples: J. Baker, G. Bergstrom, D. Bland,
B. Brown, K. Burch, C. Griffey, R. Hunger, J. Johnson, K. Lackermann, K. McCarty, B. Mulrooney, D. Van Sanford, M. Staton, and S. Wegulo. We greatly appreciate the input of reviewers, which substantially strengthened the analysis and its presentation.

\section{LITERATURE CITED}

Agapow, P. M., and Burt, A. 2001. Indices of multilocus linkage disequilibrium. Mol. Ecol. Notes 1:101-102.

Aylor, D. E. 1999. Biophysical scaling and the passive dispersal of fungus spores: Relationship to integrated pest management strategies. Agric. For. Meteorol. 97:275-292.

Aylor, D. E. 2003. Spread of plant disease on a continental scale: Role of aerial dispersal of pathogens. Ecology 84:1989-1997.

Beerli, P., and Palczewski, M. 2010. Unified framework to evaluate panmixia and migration direction among multiple sampling locations. Genetics 185: 313-326.

Bowman, D. T. 2004. North Carolina measured crop performance: Small grains. Report No. 211. North Carolina State University, Raleigh.

Brewer, M. T., Frenkel, O., and Milgroom, M. E. 2012. Linkage disequilibrium and spatial aggregation of genotypes in sexually reproducing populations of Erysiphe necator. Phytopathology 102:997-1005.

Brown, J. K. M., and Hovmøller, M. S. 2002. Aerial dispersal of pathogens on the global and continental scales and its impact on plant disease. Science 297:537-541.

Brown, J. K. M., and Wolfe, M. S. 1990. Structure and evolution of a population of Erysiphe graminis f. sp. hordei. Plant Pathol. 39:376-390.

Buschiazzo, E., and Gemmell, N. J. 2006. The rise, fall and renaissance of microsatellites in eukaryotic genomes. BioEssays 28:1040-1050.

Chen, Y., Hunger, R. M., Carver, B. F., Zhang, H., and Yan, L. 2009. Genetic characterization of powdery mildew resistance in U.S. hard winter wheat. Mol. Breed. 24:141-152.

Cherewick, W. J. 1944. Studies on the biology of Erysiphe graminis DC. Can. J. Res. C 22:58-85.

Climate Atlas of the United States. 2015. National Climatic Data Center, National Oceanic and Atmospheric Administration. www.ncdc.noaa.gov/ cgi-bin/climaps/climaps.pl

Cowger, C., Miranda, L., Griffey, C., Hall, M., Murphy, P., and Maxwell, J. 2012. Wheat powdery mildew. Pages 84-119 in: Disease Resistance in Wheat. I. Sharma, ed. CABI, London.

Cowger, C., Parks, W. R., and Marshall, D. 2009. Appearance of powdery mildew of wheat (caused by Blumeria graminis f. sp. tritici) on Pm17-bearing cultivars in North Carolina. Plant Dis. 93:1219.

Dettman, J. R., and Taylor, J. W. 2004. Mutation and evolution of microsatellite loci in Neurospora. Genetics 168:1231-1248.

Götz, M., and Boyle, C. 1998. Haustorial function during development of cleistothecia in Blumeria graminis f. sp. tritici. Plant Dis. 82: 507-511.

Götz, M., Friedrich, S., and Boyle, C. 1996. Development of cleistothecia and early ascospore release of Erysiphe graminis DC. f. sp. tritici in winter wheat in relation to host age and climatic conditions. Z. Pflanzenk. Pflanzen. 103:134-141.

Griffey, C. A., Rohrer, W. L., Pridgen, T. H., Brooks, W. S., Chen, J., Wilson, J. A., Nabati, D., Brann, D. E., Rucker, E. G., Behl, H. D., Vaughn, M. E., Sisson, W. L., Randall, T. R., Corbin, R. A., Kenner, J. C., Dunaway, D. W., Pitman, R. M., Bockelman, H. E., Gaines, C., Long, D. L., McVey, D. V., Cambron, S. E., and Whitcher, L. 2005a. Registration of 'McCormick' wheat. Crop Sci. 45:416-417.

Griffey, C. A., Rohrer, W. L., Pridgen, T. H., Brooks, W. S., Chen, J., Wilson, J. A., Nabati, D., Brann, D. E., Rucker, E. G., Behl, H. D., Vaughn, M. E., Sisson, W. L., Randall, T. R., Corbin, R. A., Kenner, J. C., Dunaway, D. W., Pitman, R. M., Bockelman, H. E., Gaines, C., Long, D. L., McVey, D. V., Cambron, S. E., and Whitcher, L. 2005b. Registration of 'Tribute' wheat. Crop Sci. 45:419-420.

Hermansen, J. E., Torp, U., and Prahm, L. P. 1978. Studies of transport of live spores of cereal mildew and rust fungi across the North Sea. Grana 17:41-46.

Holmes, G. J., Main, C. E., and Keever, Z. T., III. 2004. Cucurbit downy mildew: A unique pathosystem for disease forecasting. Pages 69-80 in: Advances in Downy Mildew Research-Volume 2, Developments in Plant Pathology. P. Spencer-Phillips and M. Jeger, eds. Springer International, Dordrecht.

Jevtic, R., Pribakovic, M., Stojanovic, S., and Leath, S. 1991. Screening the virulence of Erysiphe graminis DC. Ex Merat f. sp. tritici Em. Marchal in mobile nurseries. Plant Prot. 42:21-31.

King, D. G. 2011. Evolution of simple sequence repeats as mutable sites. In: Tandem Repeat Polymorphisms: Genetic Plasticity, Neural Diversity and Disease. A. Hannan, ed. Landes Bioscience and Springer Science+Business Media.

Kolmer, J. A. 2005. Tracking wheat rust on a continental scale. Curr. Opin. Plant Biol. 8:441-449. 
Koltin, Y., and Kenneth, R. 1970. The role of the sexual stage in the oversummering of Erysiphe graminis DC. f. sp. hordei Marchal under semi-arid conditions. Ann. Appl. Biol. 65:263-268.

Leath, S., and Bowen, K. L. 1989. Effects of powdery mildew, triadimenol seed treatment, and triadimefon foliar sprays on yield of winter wheat in North Carolina. Phytopathology 79:152-155.

Leath, S., and Murphy, J. P. 1985. Virulence genes of the wheat powdery mildew fungus, Erysiphe graminis f. sp. tritici in North Carolina. Plant Dis. 69:905.

Librado, P., and Rozas, J. 2009. DnaSP v5: A software for comprehensive analysis of DNA polymorphism data. Bioinformatics 25:1451-1452.

Limpert, E., Felsenstein, F. G., and Andrivon, D. 1987. Analysis of virulence in populations of wheat powdery mildew in Europe. J. Phytopathol. 120:1-8.

Limpert, E., Godet, F., and Müller, K. 1999. Dispersal of cereal mildews across Europe. Agric. For. Meteorol. 97:293-308.

Liu, S., Griffey, C. A., and Saghai-Maroof, M. A. 2001. Identification of molecular markers associated with adult plant resistance to powdery mildew in common wheat cultivar Massey. Crop Sci. 41:1268-1275.

Mack, R. N., Barrett, S. C. H., DeFur, P. L., MacDonald, W. L., Madden, L. V., Marshall, D., McCullough, D. G., McEvoy, P. B., Nyrop, J. P., Reichard, S. E. H., Price, K. J., and Tolin, S. A. 2002. Predicting invasions of nonindigenous plants and plant pests. National Academy Press, Washington, DC.

Mantel, N. 1967. The detection of disease clustering and a generalized regression approach. Cancer Res. 27:209-220.

Matschiner, M., and Salzburger, W. 2009. TANDEM: Integrating automated allele binning into genetics and genomics workflows. Bioinformatics 25 : 1982-1983.

Nagarajan, S., and Singh, D. V. 1990. Long-distance dispersion of rust pathogens. Annu. Rev. Phytopathol. 28:139-153.

Namuco, L. O., Coffman, W. R., Bergstrom, G. C., and Sorrells, M. E. 1987. Virulence spectrum of the Erysiphe graminis f. sp. tritici population in New York. Plant Dis. 71:539-541.

Niewoehner, A. S., and Leath, S. 1998. Virulence of Blumeria graminis f. sp. tritici on winter wheat in the eastern United States. Plant Dis. 82: 64-68.

O'Hara, R. B., and Brown, J. K. M. 1997. Spatial aggregation of pathotypes of barley powdery mildew. Plant Pathol. 46:969-977.

Oberhaensli, S., Parlange, F., Buchmann, J. P., Jenny, F. H., Abbott, J. C., Burgis, T. A., Spanu, P. D., Keller, B., and Wicker, T. 2011. Comparative sequence analysis of wheat and barley powdery mildew fungi reveals gene colinearity, dates divergence and indicates host-pathogen co-evolution. Fungal Genet. Biol. 48:327-334.

Owen, P. G., Pei, M., Karp, A., Royle, D. J., and Edwards, K. J. 1998. Isolation and characterization of microsatellite loci in the wheat pathogen Mycosphaerella graminicola. Mol. Ecol. 7:1611-1612.

Parks, R., Booth, W., and Cowger, C. 2011. Characterization of polymorphic loci of Blumeria graminis f. sp. tritici, the cause of powdery mildew in wheat. Mol. Ecol. Resour. 11:586-589.

Parks, R., Carbone, I., Murphy, J. P., and Cowger, C. 2009. Population genetic analysis of an Eastern U.S. wheat powdery mildew population reveals geographic subdivision and recent common ancestry with U.K. and Israeli populations. Phytopathology 99:840-849.

Parks, R., Carbone, I., Murphy, J. P., Marshall, D., and Cowger, C. 2008. Virulence structure of the eastern U.S. wheat powdery mildew population. Plant Dis. 92:1074-1082.

Parlange, F., Oberhaensli, S., Breen, J., Platzer, M., Taudien, S., Šimková, H., Wicker, T., Doležel, J., and Keller, B. 2011. A major invasion of transposable elements accounts for the large size of the Blumeria graminis $\mathrm{f}$. $\mathrm{sp}$. tritici genome. Funct. Integr. Genomics 11:671-677.
Peakall, R., and Smouse, P. E. 2006. GENALEX 6: Genetic analysis in Excel. Population genetic software for teaching and research. Mol. Ecol. Notes 6: 288-295.

Persaud, R. R., and Lipps, P. E. 1995. Virulence genes and virulence gene frequencies of Blumeria graminis f. sp. tritici in Ohio. Plant Dis. 79: 494-499.

Smouse, P. E., and Long, J. C. 1992. Matrix correlation analysis in anthropology and genetics. Yearb. Phys. Anthropol. 35:187-213.

Spanu, P. D., Abbott, J. C., Amselem, J., Burgis, T. A., Soanes, D. M., Stüber, K., van Themaat, E. V. L., Brown, J. K. M., Butcher, S. A., Gurr, S. J., Lebrun, M.-H., Ridout, C. J., Schulze-Lefert, P., Talbot, N. J., Ahmadinejad, N., Ametz, C., Barton, G. R., Benjdia, M., Bidzinski, P., Bindschedler, L. V., Both, M., Brewer, M. T., Cadle-Davidson, L., Cadle-Davidson, M. M., Collemare, J., Cramer, R., Frenkel, O., Godfrey, D., Harriman, J., Hoede, C., King, B. C., Klages, S., Kleemann, J., Knoll, D., Koti, P. S., Kreplak, J., López-Ruiz, F. J., Lu, X., Maekawa, T., Mahanil, S., Micali, C., Milgroom, M. G., Montana, G., Noir, S., O’Connell, R. J., Oberhaensli, S., Parlange, F., Pedersen, C., Quesneville, H., Reinhardt, R., Rott, M., Sacristán, S., Schmidt, S. M., Schön, M., Skamnioti, P., Sommer, H., Stephens, A., Takahara, H., Thordal-Christensen, H., Vigouroux, M., Weßling, R., Wicker, T., and Panstruga, R. 2010. Genome expansion and gene loss in powdery mildew fungi reveal tradeoffs in extreme parasitism. Science 330:1543-1546.

Stein, N., Herren, G., and Keller, B. 2001. A new DNA extraction method for high-throughput marker analysis in large genome species such as Triticum aestivum. Plant Breed. 120:354-356.

Svec, M., and Miklovicova, M. 1998. Structure of populations of wheat powdery mildew (Erysiphe graminis DC f. sp. tritici Marchal) in Central Europe in 1993-1996: I. Dynamics of virulence. Eur. J. Plant Pathol. 104:537-544.

Szabo, L. J. 2007. Development of simple sequence repeat markers for the plant pathogenic rust fungus Puccinia triticina. Mol. Ecol. Notes 7:92-94.

Teich, A. H. 1986. Harus soft white winter wheat. Can. J. Plant Sci. 66: 161-163.

Troch, V., Audenaert, K., Wyand, R. A., Haesaert, G., Höfte, M., and Brown, J. K. M. 2014. Formae speciales of cereal powdery mildew: Close or distant relatives? Mol. Plant Pathol. 15:304-314.

Tucker, M. A., Moffat, C. S., Ellwood, S. R., Tan, K. C., Jayasena, K., and Oliver, R. P. 2014. Development of genetic SSR markers in Blumeria graminis f. sp. hordei and application to isolates from Australia. Plant Pathol. 64:337-343.

Turner, D. M. 1956. Studies on cereal mildew in Britain. Trans. Br. Mycol. Soc. 30:495-506.

Wicker, T., Oberhaensli, S., Parlange, F., Buchmann, J. P., Shatalina, M., Roffler, S., Ben-David, R., Doležel, J., Simková, H., Schulze-Lefert, P., Spanu, P. D., Bruggmann, R., Amselem, J., Quesneville, H., Ver Loren van Themaat, E., Paape, T., Shimizu, K. K., and Keller, B. 2013. The wheat powdery mildew genome shows the unique evolution of an obligate biotroph. Nat. Genet. 45: 1092-1096

Wolfe, M. S., Brändle, U., Koller, B., Limpert, E., McDermott, J. M., Müller, K., and Schaffner, D. 1992. Barley mildew in Europe: Population biology and host resistance. Euphytica 63:125-139.

Wolfe, M. S., and Knott, D. R. 1982. Populations of plant pathogens: Some constraints on analysis of variation in pathogenicity. Plant Pathol. 31:79-90.

Wolfe, M. S., and Schwarzbach, E. 1978. Patterns of race changes in powdery mildews. Annu. Rev. Phytopathol. 16:159-180.

Worrall, W. D., Porter, K. B., Lazar, M. D., Gomez, M. H., Marshall, D. S., Nelson, L. R., and McDaniel, M. E. 1995. Registration of 'TAM-109' wheat. Crop Sci. 35:1223.

Wyand, R. A., and Brown, J. K. M. 2003. Genetic and forma specialis diversity in Blumeria graminis of cereals and its implications for host-pathogen coevolution. Mol. Plant Pathol. 4:187-198. 